\title{
Stanisław Fel
}

The John Paul II Catholic University of Lublin, Poland

Magdalena Zdun

Cracow University of Economics, Poland

\section{Judaism and Economics: The Link between Judaism and Economic Life}

\begin{abstract}
This article deals with the relationship of Judaism to economic activity. The subject is the typical approach of Jewish ethical thought, concerning the understanding of money, wealth, jobs and economic initiatives. Issues related to fundamental economic life are shown to be covered in the books that the Jewish community considers sacred. Particularly important are the Old Testament and the Talmud. Also important are references to the cultural interpretation of Judaism, including the classical works on the subject - Jacques Attali and Werner Sombart. The key concept is the subject of "wealth," the meaning of which is derived from the Bible's Book of Exodus and the Talmud. Finally, the foundations for Jewish economic thought can be expressed as the product of an embedded culture, which is founded on religion, in which property acquires ethical legitimacy. The argument is crowned with historical examples of the noble economic activity of the Jewish people, which also give evidence of the interrelatedness of religion and the proper use of wealth.
\end{abstract}

\section{Keywords}

Judaism, Economics, Entrepreneurship, Business ethics, Wealth, Philanthropy, Investment, Vocation, Money, Accountancy.

\section{Introduction}

Much has been written about the influence of culture, and particularly of religion, on economic life. First amongst the classic authors on this subject is Max Weber, whose frequently quoted work, "The Protestant Ethic and the Spirit of Capitalism" argues for a precise link between Calvin's teachings and 
the entrepreneurship of Western Europe ${ }^{1}$. Weber's work long reigned over the sociological discourse about entrepreneurship, and is partly responsible for having narrowed the cultural debate about economic life to one, from amongst many possible factors. Despite the powerful influence of his scholarship, the German researcher failed to prevent subsequent scholars from demonstrating evidence of the influences of other religions of economic activity. Among them are scholars of Jewish culture and Judaism.

The link between Judaism and economic activity is interesting for at least two reasons. Firstly, because the Jewish religion permeates all dimensions of the life of the community, rather than being merely a formal part of a wider culture. "Studying the Torah - Arnold Goldberg notes - it is a commandment, and every Jew is obliged to learn as much about it, as possible. Thus the Jews became a Scriptural people (...) but not in the sense of intellectual study, which requires the comprehension of a large set of complicated material, which would make high demands on the intelligence of the reader. Rather, it is a liturgical form of learning, which understands this activity in terms of a person's service to God"2. Thanks to the people's approach to the study of sacred texts, the Jewish religion came to be a determining factor in all realms of activity, including those related to the acquisition of money. Secondly, the relationship between Judaism and economic activity is interesting because of the historical trail, which it has left in the world and in particular in Polish national history.

So how does one define the relationship between Judaism and economic life? In what way has it inspired and guided entrepreneurship?

\section{The essence of Judaism - journey and enrichment for God}

For Jacques Attali, the essence of Judaism is derived from the biblical stories of the book of Exodus. "Judaism - writes the prominent French intellectual - begins in travel"3. His sources stem from the desert through

1 M. Weber, Etyka protestancka a duch kapitalizmu (The Protestant Ethic and the Spirit of Capitalism), Lublin 1994, Wydawnictwo Test.

2 A. Goldberg, Judaizm (Judaism), in: E. Brunner-Traut (ed.), Pięć wielkich religii świata (The five great religions of the world), Warszawa 2001, Instytut Wydawniczy PAX, p. 134.

3 J. Attali, Żydzi, świat, pieniadze (The Jews, the World, the Money), Warszawa 2003, Wydawnictwo Cyklady, p. 13. 
which Moses traversed; the significant theme of which was the wanderings of a weary people. The journey from Egypt toward Israel began a great era in the history of the nation, while providing a basis for the explanation of its social character. For Jacques Attali, the Exodus has risen to a central, symbolic point of reference for the explanation of many social matters. Thus, it is wise to make continual reference to the Exodus, as a key to the successful interpretation of cultural phenomena. The key in the story, to which Attali points, is both the very fact of the migration, as well as the "ideological breakthrough", which took place at that time. The journey determined the fate of the community of brothers in faith, and in turn, this landmark event defined the norms and standards for the conduct of the nation, which lay the foundation for many types of social activity, including economic activity.

It all began with the Exodus from Egypt. The Jewish exiles came from the land of the Pharaoh, enriched with stolen gold. The Bible writes about this event in the following words: "But I shall bring judgment on the nation that enslaves them, and after this, they will leave with many possessions (Gen 15, 14). Thus began the great migration, and there came a time for a painful lesson in economics. It turns out that gold, taken from the Egyptians, is not the key to economic success ${ }^{4}$. Wearied and discouraged by Moses' command, the wanderers set upon a rebellion. They decided to honor what, not long ago, was the subject of ridicule. Following the example of their former Egyptian captors, they accumulated their gold and valuables to build a calf, which they intend to worship, as a divinity. Aaron's appeals were unsuccessful when he tried to ridicule the project, and at least, to slow its progress ${ }^{5}$. The Israelites chose to bow in worship before wealth, which served only themselves, and nothing more. As Attali commented this event, "Money, a tool in the service of God, became His rival, the subject of idolatry, a dangerous tool when it becomes an end in itself. In other words, enrichment when not included in the framework of moral principles, is a form of idolatry" .

The cult of gaining wealth for its own sake interrupted the return of Moses, who in anger had burned the idol, undermining the accumulation of wealth by all the people. As Attali proposes, this event soon became recognized as an ideological breakthrough, and a fundamental lesson of economics. In the

\footnotetext{
4 Ibid., p. 23.

5 Ibid., p. 24.

6 Ibid.
} 
place of the looted treasures, Moses gave the people the Law, which God had dictated to him. The Decalogue thus became a new "moral framework" for any and all social activity, including economic matters. The task was set before the Israelite nation, "that its main wealth shall be the kind of good, which will is not able neither to be sold nor consumed"7. The Law is this "good". The new code and commandment, given by Yahweh, took the place of the value of the gold. The adoption and implementation of the Law henceforth became the foundation and stimulus for all actions.

This story, contained in the book of Exodus, thus became the key to interpretation in Judaism for matters concerning economic engagement. Attali's analysis points to an important thesis: the norms of a given religious group are an appropriate catalyst and governor of economic activity. These are found in the commandments, that is, the Law of God - the imperatives which were given on Mount Sinai. Consequently, the worship of wealth - in terms presented here - has no legitimacy, if it serves only one's self. It only makes sense when it gladdens Yahweh, because His will is being fulfilled ${ }^{8}$. Thus, the Exodus of the Israelites must be the starting point, for reflection on the relationship between Judaism and economic life. This symbolic event directs the search for the causes of a "race for material things" in the direction of what is elusive, spiritual, determined by culture, and an especially essential part of it - religion.

\section{3. "To be" and "to have" - the mystery of the Hebrew language, and its relationship with the Jewish economy}

Understanding the peculiarities of Jewish thought in the economic context is also facilitated by a presentation of a rudimentary analysis of the Hebrew terms connected with economic activity, congruently with Jacques Attali's arguments. It is significant that the Hebrew language does not contain the word "have". The relationship of possession in this language is expressed through seemingly opposite terms - "jesh" means, "to be". How then is it possible

7 Ibid., p. 24.

8 M. Tamari, Punkt widzenia judaizmu na wspótczesna moralność przedsiębiorczości (The point of view of Judaism to contemporary morality entrepreneurship), in: P. M. Minus (ed.), Etyka w biznesie (Ethics in Business), Warszawa 1998, PWN, p. 105-106. 
to express "ownership" through "being?" Erich Fromm treats the terms "to have" and "to be" to be treated, as opposites. He notes that the means of being and the means of possession and being are two contradictory ways of functioning in the world, and two completely distinct life orientations. Fromm writes: "[they are] two different references to the world and to each other, two different types of character, which have primary and awarded status, which define the whole of human thought, feeling and action"". It is not by accident, therefore that Fromm, in the title of his book, separates the terms "to be" and "have" with the particle "or", and closes it with a question mark, thus pointing to the contrasting meanings of these terms. How, then, is this hurdle overcome in Judaism? "The word 'jesh' - Attali notes - which means 'to be' or 'is' determines the relationship of 'that which is' to its subject. (...) In other words, the thing possessed is defined by its possessor ${ }^{10}$.

An analysis of the word, kesef, used to denote money, is also important. Its direct translation refers to the terms "desire" and "longing"". In turn, leshalem, meaning "payment" can be read as shalom, which means "peace". The final significant term is sha'ar, ("value") which also translates, "city gate", that is, the place where the terms of justice were normally imposed ${ }^{12}$. Analysis of these concepts, in the context of the story from the Book of Exodus sheds light upon items which are relevant to economic life, according to the characteristic features of Jewish thought. The first important element is the Law and the "worthwhile thing", to which it points. This element makes the search for "the entrepreneurial spirit" - to use a phrase of Max Weber - culturally imponderable. The second important element is the union of seemingly contradictory terms: "to be" and "to have". "Possession" is understood as part of selfhood; "objects live the life of a shepherd"13. "Having" thus makes sense of "being," and "being" determines the importance of "having". The third important element of this approach regards pay and money. The fee is recognized here in the context of longing for justice, so "repaying debts is a means to peace"14, and money is a means to the administration of justice.

\footnotetext{
9 E. Fromm, Mieć czy być ? (To have or to be?), Poznań 1999, Dom Wydawniczy Rebis, p. 66.

${ }^{10}$ J. Attali, Żydzi, świat, pieniagdze (The Jews, the World, the Money), p. 26.

${ }^{11}$ Ibid.

12 Ibid., p. 28.

${ }^{13}$ Ibid., p. 26.

14 Ibid., p. 28.
} 


\section{The Talmud - "The Bible for the rich"}

Subsequent principles for the administration of financial matters are found in an extremely significant book for the Jews - the Talmud. The book was written in order to strengthen the integrity of the Jewish community, and to enhance the ethical dimensions of the means by which funds are transferred. It became in part, a textbook for economics. The authors were merchants, and people were employed in trade and currency transfers. According to Werner Sombart, the Talmud became the "midpoint of Jewish religious life"15, and along with books such as the Bible (Old Testament), the Code of Maimonides, the Jacob Ascher Turium code or code of Joseph Karo, it deserves to be called a pillar of the Jewish economy. What important concepts that influenced economic thought have their roots in the Talmud? First, the Talmud argues that wealth is pleasing to God. God gave man the earth, so as to derive profit from it. Hence, money can become an instrument, which can serve God; by bringing the sacred order into the profan $\mathrm{e}^{16}$. Contrary to the submissions made by Weber on the relationship of economic development of Protestantism, wealth here is not recognized in the category of the idea of predestination. Wealth is a task and a challenge for human beings, but never given by Yahweh, as a reward. Riches bring responsibilities. It is the responsibility for governing the world, or in other words: "the privilege of being useful" 17 .

Wealth, which is called to deal with the general good, is also subject to the requirement of modesty. "The rich - writes Attali - should live frugally, without pride and self-admiration, but also without false humility"18. The management of a person's fortune demands flexibility and creative freedom, therefore it can not be invested in what is a static good, such as land. The Jewish person must constantly be ready to abandon his or her present location, and the same is true of money; it journeys, too.

Wealth as described by the Talmud is not a goal in itself, but a means to other purposes. The end of economic activity is not merely in the enjoyment and satisfaction of its owner; rather, it is a ticket to greater initiatives. The

${ }^{15}$ W. Sombart, Żydzi i życie gospodarcze (The Jews and Economic Life), Warszawa 2010, IFiS PAN, p. 194.

${ }_{16}$ J. Attali, Żydzi, świat, pieniadze (The Jews, the World, the Money), p. 87.

${ }^{17}$ Ibid.

${ }^{18}$ Ibid. 
imperative to use wealth to meet the needs of others, and even to sanctify the earth, calls for it to be utilized as efficiently as possible ${ }^{19}$. Wealth mobilizes a person to take on ever more challenging projects, and to go beyond tightly circumscribed boundaries; "[It raises the need for] the crossing its very self, which has no borders"20. Joseph Kozielecki would probably at this point, add that wealth is the key to transgress limitations of a being, who has been molded from clay into "homo hubris" - having the ambition to extend beyond the borders that were set before him or her ${ }^{21}$.

Wealth expresses itself in specifically financial categories, and in doing so, serves as a measure of justice. Money must be used for the reparation for harm, and it must be the means by which fair transactions are made. According to the Talmudic fraudulent acts are among the worst and most heinous crimes. The price of the goods must be fair, and so the market must have reliable tools for weights and measures. Money needs to be earned by working: "it is better to do without the Sabbath than to be dependent on alms"22. Although a given job may be difficult, it should not be a means for humiliation. For this reason, the Talmud warns against monotonous work, that which is inordinately dependent on others and that which is steered by bad intentions. Sometimes, wage labor cannot be avoided. It should then be performed and compensated fairly. Jacques Attali notes, however, that the Talmud "better protect[s] consumers than employees" 23 . While here the text has analyzed the concept of a "fair price," a similar concept, relating to employment is lacking - that is, a "fair wage" 24 .

The person whose wealth is pleasing to Yahweh, is also called to the fight against poverty. This entails the obligation to do acts of charity for the members of the community. The aim of this is to keep the rich from living only for themselves, that they might instead strive to bring their brothers to a higher economic level. Once again, wealth is linked to the vocation of seeking

${ }^{19}$ M. Tamari, Punkt widzenia judaizmu na wspótczesna moralność przedsiębiorczości (The point of view of Judaism to contemporary morality entrepreneurship), p. 107.

20 J. Attali, Żydzi, świat, pieniadze (The Jews, the World, the Money), p. 87.

${ }^{21}$ J. Kozielecki, Transgresja $i$ kultura (Transgression and culture), Warszawa 2002, Wydawnictwo Akademickie Żak.

${ }^{22}$ J. Attali, Żydzi, świat, pieniadze (The Jews, the World, the Money), p. 92.

${ }^{23}$ Ibid., p. 93.

${ }^{24}$ Ibid. 
out opportunities to be useful for others ${ }^{25}$. This "missionary" dimension of wealth is reflected in the tax actually borne to the municipality, to be known as 'tzedakah'. The spirit of this tax has become inscribed in Jewish thought, as a goal of continually improving the world. In this way, the Jewish people have legitimized their role as the Chosen People, and have given indication, as to the nature of their calling.

\section{A nation "chosen for capitalism"}

In his analysis of the impact of the Jewish religion on economic life, Werner Sombart would probably call the Jewish nation, one that was "chosen for capitalism". This researcher has devoted an extensive study to the role of Judaism and the Jews, in a book entitled "Jews and economic life" which, although judged by Attali as "peppered with factual errors and anachronisms [and acting] more or less as involuntary collection of anti-Semitic cartoons" 26 , is worth quoting for one basic reason: the book is an interesting sociological discussion of the thesis put forward by Max Weber, the proponent of the special relationship of entrepreneurial activities with Protestantism. It behooves the reader "not to treat the book in isolation: it contains reflections on the role and place of the Jews in modern society, which are in fact a direct polemical dialogue with Weber's "protestant hypothesis"27. It is also noteworthy that Sombart's analysis does not only concern religion and its relationship to the actions of the capitalists, but he also considers it significant that the group in question is steeped in a socially exceptional situation, which is distinct from that of other religious groups. As such, Werner Sombart identifies four basic characteristics of this group. These are: the dispersion in space, their foreignness, their status as "part-nationals", and their wealth ${ }^{28}$. These features inclined this particular religious group to be internally cohesive, and its members to be in close solidarity with one another. At the same time, they were motivated to undertake entrepreneurial activities which tended to

${ }^{25}$ Ibid., p. 95.

${ }^{26}$ Ibid., p. 273.

${ }^{27}$ H. Szlajfer, Żydzi Wernera Sombarta (Werner Sombarts Jews), Wstęp do (Introduction to) W. Sombart, Żydzi i życie gospodarcze (The Jews and Economic Life), XV.

${ }^{28}$ W. Sombart, Żydzi i życie gospodarcze (The Jews and Economic Life), p. 166. 
break with whatever had been routine. As foreigners and "part-nationals", or ones who were not granted full social privileges, the Jewish people were posed with special obstacles, and so they mobilized themselves to take on various initiatives, while often being met with wide-scale objection. So although various trade restrictions were imposed upon the Jews, (for example, the Berlin Jews were forbidden to sell vodka and meat to the non-Jewish population) they did their best to procure licenses and patents governing the sale of other goods" ${ }^{29}$. [The Jewish people] - notes Sombart - were considered by the established populations to be intruders. Their social energy stimulated a spirit of freedom. They think about how to gain a foot in a new environment" ${ }^{30}$. Consequently, their "foreignness" is not only a limitation, but it becomes an opportunity, and stimulus for economic activity. Their sense of alienation, according to Sombart, creates a socially comfortable situation. With strangers, you can negotiate a more unrestrained way, which reveals their strength, both in their capacity as dealers and buyers.

The group's features have support, but do not explain the motive of the Jewish people's approach to economic activity. The determining factor in the thesis that the Jewish people are "created for capitalism" is no less than their religion, which, as Sombart noted, here is not just a matter of observing holidays. Religion permeates and shapes the whole life of the Jewish person, with respect to everyday life, behavior, work and decisions related to the family. "Religion - says Werner Sombart - has sanctified all the relationships of a Jewish person's life. Before taking any action or making any omission, he or she gives consideration, as we already know, and as we shall demonstrate in detail, as to whether or not this action gives glory or rather is offensive to the divine majesty"31. On the basis of such values, economic activity is sanctified when it implements the provisions of Sacred Scripture; and is deemed wicked - when it opposes them. So what are those seminal ideas, which are contained in the sacred writings of Judaism? Werner Sombart points to two basic ideas of Judaism's approach to capitalism. The first is the "contractual arrangement of life" 32 . "I would call it - says Sombart - the settlement of all relations between Jehovah and Israel on practices of

\footnotetext{
${ }^{29}$ Ibid., p. 174.

${ }^{30}$ Ibid., p. 171.

${ }^{31}$ Ibid., p. 189.

32 Ibid., p. 204.
} 
merchants" ${ }^{\prime 3}$. The conventional approach to one's relationship with God, is reflected in the conventional treatment of human interactions. Accountancy shapes these relationships, and ultimately also makes them righteous. At the same time, it also determines the rules of negotiation, allowing ways for haggling and the collection of debts. The contractual arrangement lies in the understanding, that the obligations which are fulfilled earn a prize, while the failure to do so, yields a penalty. Human life is nothing other than an account on which bills are tabulated. A fair assessment of the human condition for this reason necessitates the keeping of constant calculations. That tendency towards bookkeeping and accountancy, and the establishment of conventional contracts gives Judaism most congenial relations with capitalism.

Judaism, like capitalism readily embraces a rationalized approach to living. Holiness - as argues our often-quoted author Werner Sombart - depends upon living a "life according to an ideal plan (...)"34. And further: "holiness must be understood as the process by which rational behavior replaces our natural, instinctive existence through contrived, deliberate, ethical living" ${ }^{35}$.

\section{Money sanctified and the "commandment for enrichment," to make the world a better place - the contemporary followers of Judaism and Economics}

The relationship between Judaism and the economy has been studied not only by leading Gentile scholars, but also by current Jewish religious thinkers. "Money - notes Rabbi Shalom Berem Stambler - is something powerful" ${ }^{36}$. It is the product of work, which is defined in the Talmud, to be an obligation of the Jewish person. "In the Talmud - says Stambler - it is said that it is better to strip the skin of a dead animal, in order to have enough to eat, and so to do something that is forbidden of proper Jews, than to do nothing, and to ask others for money ${ }^{37}$. As Attali argued, work is therefore, a basic activity, or as

${ }^{33}$ Ibid.

${ }^{34}$ Ibid., p. 222.

${ }^{35}$ Ibid.

${ }^{36}$ Sz.B. Stambler, F. Memches, Ekonomia $w$ Judaizmie. $Z$ rabinem Szalomem Berem Stamblerem rozmawia Filip Memches (Economics in Judaism. With Rabbi Shalom Ber Stambler speaking Filip Memches), Warszawa 2011, MDI Books, p. 25.

${ }^{37}$ Ibid. 
Weber would say - the calling of a Jew. The obligation to work, as recorded in the Talmud, sanctifies its fruits. "If one's money was not stolen, nor obtained by fraud, and if one's tithe has been paid, then that money has become something different than before. It is, as if it had been blessed" - notes Rabbi Stambler ${ }^{38}$.

Sanctified by God's command, the Jewish people are motivated to take on diverse economic activity. Historical records and literary images suggest how great that calling has been. Attali describes the economic activity of the Jewish people, from the beginning of the ninth century in these words: "The Jews have undertaken various professions: doctors, clothiers, tanners, wheelwrights, tailors, carpenters, blacksmiths, jewelers and carpenters" 39 .

Judaism presents its followers with a goal of responsible prospering, and consequently, it is proper to exhibit one's love for God by fulfilling this vocation. Similarly, one's inheritance gains legitimacy in the eyes of Judaism. Therefore, Rabbi Stambler argues, "money in the first place should serve sacred matters" $"$. Finally, there a spiritual dimension in the accumulation of material wealth. It comes down to making sense of life, and knowing "who serves whom"4l. The agglomeration of wealth for one's own selfish purposes does not enjoy the support of the Jewish faith. One's fortune is to help change the world, and its acquisition is thus a kind of imperative or an injunction. In this sense, carrying out the "commandment of getting rich" coincides with the realization of God's plans.

\section{Industrial Łódź and the history of the great financier Leopold Kronenberg - a historical illustration of the Jewish economics, as a short summary}

There are many historical examples of this approach to living out an economic vocation from Yahweh. The most striking example is the economic activity of the Jews and the eminent businessman and banker Leopold Kronenberg in the Polish city of Łódź, during the $19^{\text {th }}$ century. The economic

${ }^{38}$ Ibid., p. 26.

39 J. Attali, Żydzi, świat, pieniadze (The Jews, the World, the Money), p. 115.

${ }^{40}$ Sz. B. Stambler, F. Memches, Ekonomia $w$ Judaizmie. $Z$ rabinem Szalomem Berem Stamblerem rozmawia Filip Memches (Economics in Judaism. With Rabbi Shalom Ber Stambler speaking Filip Memches), p. 40.

${ }^{41}$ Ibid., p. 39. 
development of Łódź until the outbreak of World War I was very exuberant. Łódź became an island of industry and economic initiative in the occupied Polish territories. In the years 1822-1913, the number of employees in textile manufacturing increased from 2 to 94 thousand workers. During that time, over 550 textile companies were established. There was also spectacular growth in the craft sector. In the years 1821-1913 about 1,500 manufacturing plants sprang up. Merchandising in Łódź fared even better. From a mere 26 stores, within less than a century, their number grew to include 4,000 additional shops $^{42}$. Banks and credit unions arose, which would eventually amass almost $20 \%$ of the cash in all the companies of the Polish Kingdom ${ }^{43}$. The majority of all these projects was carried out by the Jews. It is through their efforts that the city was transformed into an impressive industrial hub. As noted by Wieslaw Puś, almost $90 \%$ of the trading companies were run by Jewish merchants, the most well-known of whom were: Mendel Moszkowicz, Lewka Jakubowicz, Morche Boruch and Simon Moszkowicz ${ }^{44}$. It is noteworthy that during the time of rapid growth of the city of Łódź, the new arrivals were mostly Jewish ${ }^{45}$. This means that the city has become a place that had been chosen for the projects recorded in a vocation found in Sacred Scripture. At the end of the nineteenth century, due to the economic activity of the Jewish people, Łódź became an important center for financial institutions. The first joint-stock bank was established at the initiative of David Rosenblum and Louis Starkman. Equally important and economically stimulating initiatives were taken up by those who set up subsidiaries, as well as home bankers. The first such institution was established in the home of bankers William Landaun and Adolf Goldfelder ${ }^{46}$. The lesser part of the Jewish economic activity took the form of craftsmanship. This group represented $20 \%$ of all those employed in the craft industries ${ }^{47}$. The leading part of the Jewish population was composed of industrialists, as is evidenced by just a few names of some major manufacturers, including: Szaja Rosenblatt - the owner of a wool factory,

${ }^{42}$ W. Puś, Żydzi w Łodzi w latach zaborów 1793-1914 (The Jews of Łódź between the Partitions 1793-1914), Łódź 1998, Wydawnictwo Uniwersytetu Łódzkiego, p. 50.

${ }^{43}$ Ibid., p. 223.

${ }^{44}$ Ibid., p. 51.

${ }^{45}$ A. Machejek (ed.), Żydzi łódzcy (Jews of Lodz), Łódź 2005, Wydawnictwo Hamal, p. 21.

${ }^{46}$ W. Puś, Żydzi w Lodzi w latach zaborów 1793-1914 (The Jews of Łódź between the Partitions 1793-1914), p. 63.

47 Ibid., p. 69. 
or Herman Konstant - owner of the brewery and commissioner of textile products $^{48}$. Other large Jewish establishments were the wool plant of Mosze Aaron Wiener, and the Siberstein family's factory ${ }^{49}$.

As proof of the great scope of Jewish activity in Polish lands, in addition to industrial Łódź, we should mention another outstanding individual - the financial giant Leopold Kronenberg. He is described as: "a man of great stature - an efficient entrepreneur, banker and merchant, who initiated a number of infrastructure projects, a patron of culture, and was even an editor" ${ }^{50}$. He was a pioneer, and a symbol of Polish capitalism, the initiator of reforms and political activist. For Kronenberg, his assets were not a goal in itself, but rather a method, by which to make the world a better, fairer place. Kronenberg was raised in this spirit, and elements of Jewish ethics in his resumé are easy to spot. It was he who, during the January Uprising created the "White Organization", a cooperative, which worked for liberation through economic means. In this way, - says Andrzej Żor - he "gained a reputation as the moving spirit of one of the two main factions of society" 51 . Kronenberg was delighted with the emerging railway system in England, and he financed the construction of Vistula Valley Railways ${ }^{52}$. This banker expanded his involvement to include entrepreneurship, as well as social innovation and reform. His life became an exemplification of the Jewish ethos that, "the leading values are wisdom and knowledge. Unlike in Protestant Puritanism, for the Jewish person, property is not a value alone by itself, nor is it an outward sign of charisma. Assets can be a means to achieve the highest values - wisdom and knowledge" ${ }^{53}$. Finally, the examples mentioned above serve as a kind of summary of the analysis presented earlier. They highlight the relationship of Judaism to economic activity, while pointing to the fundamental principle of Jewish ethics. This principle is the primacy of the spiritual over the material, which prioritizes God and his name, as the proper motive and method for enrichment.

48 A. Machejek, (ed.), Żydzi łódzcy (Jews of Lodz), p. 22-26.

${ }^{49}$ W. Puś, Żydzi w Lodzi w latach zaborów 1793-1914 (The Jews of Łódź between the Partitions 1793-1914), p. 92-93.

${ }^{50}$ S. Sikora, Przedmowa do (Preface to) A. Żor, Kronenberg. Dzieje fortuny (Acts of Fortune), Warszawa 2011, PWN, p. VII.

${ }^{51}$ A. Żor, A. Żor, Kronenberg. Dzieje fortuny (Acts of Fortune), p. 297.

${ }^{52}$ Ibid., p. 185.

${ }^{53}$ A. Hertz, Żydzi w kulturze polskiej (The Jews in Polish Culture), Warszawa 2003, Biblioteka Więzi, p. 115. 


\section{Bibliography}

Attali J., Żydzi, świat, pieniądze, Warszawa 2003, Wydawnictwo Cyklady.

Fromm E., Mieć czy być?, Poznań 1999, Dom Wydawniczy Rebis.

Goldberg A., Judaizm, in: E. Brunner-Traut (ed.), Pięć wielkich religii świata, Warszawa 2001, Instytut Wydawniczy PAX.

Hertz A., Żydzi w kulturze polskiej, Warszawa 2003, Biblioteka Więzi.

Kozielecki J., Transgresja i kultura, Warszawa 2002, Wydawnictwo Akademickie Żak.

Machejek A. (ed.), Żydzi łódzcy, Łódź 2005, Wydawnictwo Hamal.

Puś W., Żydzi w Łodzi w latach zaborów 1793-1914, Łódź 1998, Wydawnictwo Uniwersytetu Łódzkiego.

Sikora S., Przedmowa do A. Żor, Kronenberg. Dzieje fortuny, Warszawa 2011, PWN.

Sombart W., Żydzi i życie gospodarcze, Warszawa 2010, IFiS PAN.

Stambler Sz. B., Memches F., Ekonomia $w$ Judaizmie. Z rabinem Szalomem Berem Stamblerem rozmawia Filip Memches, Warszawa 2011, MDI Books.

Szlajfer H., Żydzi Wernera Sombarta, Wstęp do: W. Sombart, Żydzi i życie gospodarcze, Warszawa 2010, IFiS PAN.

Tamari M., Punkt widzenia judaizmu na współczesna moralność przedsiębiorczości, in:

P. M. Minus (ed.), Etyka w biznesie, Warszawa 1998, PWN.

Weber M., Etyka protestancka a duch kapitalizmu, Lublin 1994, Wydawnictwo Test.

Żor A., Kronenberg. Dzieje fortuny, Warszawa 2011, PWN. 